\title{
Towards understanding theological positions informing migrant ministries
}

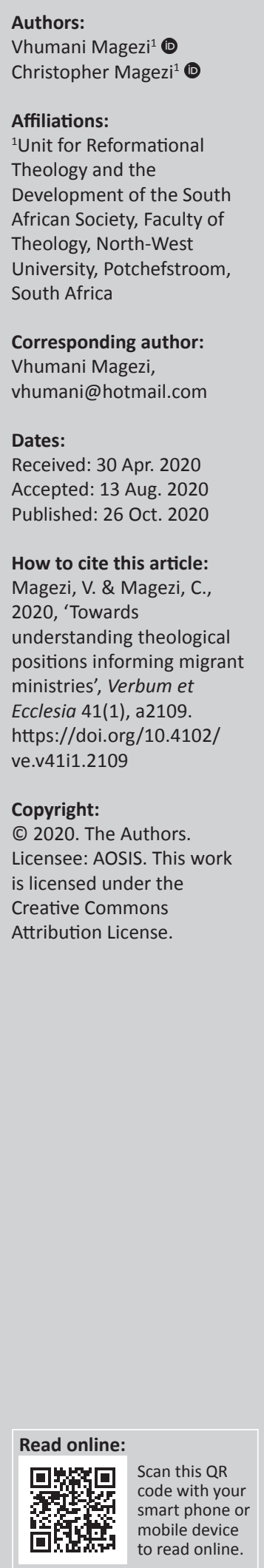

Christian practical ministry should be driven by a thorough theological framework. Theological theory informs ministerial practices. To understand some theology driven (theologies driving) actions, it is imperative to conduct empirical studies to discern some grassroots theologies held by church leaders on the frontline of ministry. With migration as a challenge of our times that requires churches to intervene, the question that emerges is: what are the theological views and perspectives held by church leaders that drive migrants' ministry? In answering this question, this article presents empirical findings of a study conducted in South Africa's province of Gauteng. To locate the study within a South African context, the article devotes a substantial section on migration in South Africa. The findings revealed diversity in theological views and perspectives as well as limitations on critical biblical and theological understanding on migrant ministry as a holistic ministry. In their reflections, some church leaders showed superficial understanding of the Biblical texts, lacked contextual understanding of texts and their theology was not well thought out and integrated into the broader biblical and theological understanding.

Intradisciplinary and/or interdisciplinary implications: The study integrates systematic theology, biblical texts and practical theology in discerning emerging theological views and perspectives amongst church leaders. The study contributes to gaining insight into underlying theologies that motivate migrant ministry interventions.

Keywords: migrant ministry theology; migrant church ministry; migration theology; migration theology in South Africa; pastors views on migration in South Africa; South Africa migration; migration and holistic mission in South Africa; church leaders and migration.

\section{Introduction and study premise}

Migration is one of the major challenges facing the world. By 2015, the United Nations Human Rights Commission (UNHRC 2015) noted:

$[T]$ he number of international migrants worldwide has continued to grow rapidly over the past fifteen years reaching 244 million in 2015, up from 222 million in 2010 and 173 million in 2000. (p. 1)

Goldin (2016) observed that migrants across the world make up 3\% of the global population, which makes migration a key aspect of our world. Lajčák (2018) added that the world is experiencing increased volumes in migrant populations resulting in changes in demographics and labour markets, amongst other things. The migration situation is complex and is causing burn out and compassion fatigue across the globe (Louw 2015; Schjonberg 2017). As a result of fatigue, countries are starting to be inward looking and tightly closing their borders. For instance, amidst the challenge of COVID-19 global epidemic, the President of United States of America (USA) Donald Trump, signed an executive order to stop issuing green cards for 60 days to protect American people from competing for jobs with foreign workers (Kapur 2020). Despite efforts to halt migrants, the situation is far from easy. All sectors of society including churches are grappling with migration. Writing in the context of Christian missions in the West, the missiologist Hanciles (2008) opined that it is an undeniable fact that migrants are influencing the shape of global Christianity, rather the question should be to what extent. He quipped: 'the question is not whether these new Christian communities formed by migration will impact Western society, but rather to what extent' (Hanciles 2008:3).

Churches as communities of spiritually transformed people (pneumatological beings) have a responsibility to embrace and care for other people. Elsdörfer (2019) maintained that Christianity and Christian spirituality should engage with practical challenges of people's lives. She stated: Christian spirituality 'has to be accountable for everyday encounters and actions in daily life' 
(Elsdörfer 2019:105). In this respect, theological theory should include frameworks that engage public activities for the sake of societies. Notably, within South Africa and other parts of the world, churches have been involved in responding to migrants' social, spiritual, physical, environmental, economic and psychological needs (Magezi 2018a:278-305). The churches' support has included assistance for migrants to acquire employment, legal documentation, accommodation, skills training and entrepreneurial projects, provision of food parcels, preparing meals, providing Bibles in migrants' mother-tongue languages (Chisale 2016:1-8; Magezi 2018a:278-305). South African churches have provided services that are in line with their church's mission work rooted in 'participation in God's cosmic purposes for a new order of relationships at all levels in the universe governed by justice, love, peace and grace' (Langmead 2013:69).

Despite church's efforts to address migrants' needs, it has been inadequate because of resource limitations. Apart from limited resources, some efforts have resulted in churches breaking country by-laws. For instance, Bishop Paul Verryn at the Johannesburg Central Methodist Church ended up breaking South African city by laws, whilst criminal migrants also took advantage of the situation (Mail and Guardian 2010). The other church interventions to migrants have been statements and pastoral letters issued by church leaders (World Council of Churches [WCC] 2019, Crux 2019).

Notably, studies on migration have largely focused on literature studies with little empirical studies. The positions of individual churches on migration are largely unclear despite statements by bodies such as the South African Council of Churches (SACCs) and Southern African Catholic Bishop's Conference. Therefore, it is critical to understand the theological positions held by churches as represented by their church leaders. Chisale (2016:1-8) documented Bishop Paul Verryn's pastoral response to unaccompanied refugee minors, which forms an example (a kind) of a pastoral care and mission response for the broader church's pastoral ministry. However, empirical practical theological reflection studies on migrants are scant. Migrant ministries like any other practical ministerial approaches are informed and driven by a theological theory. Practical theologians agree that practical theological approaches entail three elements, namely that (1) it begins with a base in practice, (2) moves towards theoretical reflection and (3) returns to practice (Cahalan \& Mikoski 2014; Magezi 2019). Miller-McLemore (2012:20) explained that practical theology is an activity of believers seeking to sustain a life of reflective faith in the everyday life and a method or way of analysing theology in practice used by religious leaders, teachers and students.

The importance of practical theology, as Louw (2014) noted is that it is the science of theological, critical and hermeneutical reflection on the intention and meaning of human actions as expressed in the practice of ministry and the art of faithful daily living. Interpretation of actions and their meaning to real life is an important aspect in developing theological positions in real-life situations. The theological positions provide an understanding of the underlying theoretical base driving actions. Therefore, this study aims to discern theological base serving as an engine in migrant ministries amongst some church leaders. A practical investigation on theological positions that drive churches' migrant ministries in South Africa is worth undertaking. The presupposition of the study is that a church's ministerial practice to a large extent reflects its theology. Church's practice or activity is an expression of the church's theology of practice. Bush (n.d.:1) rightly argued that theology as God-talk occurs within particular communities of faith and that it is shaped in relationship to the practices of these communities of faith'. From a contextual theological approach, it should be maintained that pastors and theologians should take seriously the context of lives of people because 'good theology keeps the church in touch with reality' (Matheny 2011:xv). The question posed in this study to understand theology of migration that drives South African churches' migrant ministries is: what are the churches theologies of migrant ministry? Stated differently, what theological perspectives and views inform South African churches' migrant ministries? To locate the study within a South African context, the article proceeds from a discussion on migration in South Africa.

\section{South Africa migration situation}

Migration is caused by push and pull factors that include natural disasters, economic instability, political instability, tourism, education and others. Naudé (2008) noted that Africa, particularly sub-Saharan African countries are characterised by people who move from their countries of origin to South Africa because of natural disasters in their countries. These natural disasters are multiple in scale and diverse in nature (The Nansen Initiative 2015).

Flooding associated with tropical cyclones, and severe drought have consistently contributed to both internal and cross-border displacement Southern Africa also experiences a range of other natural hazards including landslides, flash floods, earthquakes, tsunamis, tornados, excessive snowfall, hail storms, sand storms, land degradation, extreme temperatures and volcanic eruptions. Hazards such as these take place in broader environmental, social and political contexts impacted by inequality, poverty, violence and governance challenges. (p. 1)

When natural disasters occur in South Africa's neighbouring countries, people are forcibly displaced to South Africa. The Internal Displacement Monitoring Centre (IDMC) cited by the Nansen Initiative (2015:1) noted the existence of approximately over 1.5 million people displaced by natural disasters in Southern Africa between 2008 and 2013. Mozambicans constitute the highest number of displaced people during this period with a total of at least 500000 . For instance, Cyclone Eline that hit Mozambique in 2002, affected 5 million people and about 1.25 million moved to Southern Africa with many evacuating to South Africa for safety. The Food and Agriculture Organisation (FAO) of the United Nations (2015) predicted that the impact of tropical cyclones 
is most likely to be felt by sub-Saharan Africa countries such as Mozambique and South Africa in the forthcoming years. In subsequent years other disasters such as cyclone Idai were also experienced.

Economic instability is another push and pull factor. Economic instability results in the migration of many people from other countries moving to South Africa (Kalitanyi \& Visser 2010:377-378). By 2015, South Africa was hosting millions of people who moved from their countries of origin because of economic challenges (Fauvelle-Aymar 2015:31ff; Hammerstad 2011:1-4). Although the exact number of international migrants who moved to South Africa because of economic problems cannot be determined with certainty, Gilbert and Chiumia (2016:1) and the BusinessTech (2017) estimated that there were 3.14 million international migrants in South Africa by 2015. The reason for many foreign people migrating to South Africa is because of lack of employment, poverty and poor-quality of life in their home countries (Magezi 2018:164-177).

Many international migrants in South Africa come from the neighbouring countries, particularly the Southern African Development Community (SADC) region (Statistics South Africa 2017:27). As sub-Saharan Africa's economic leader, South Africa attracts many international migrants from the whole of Africa and beyond. South Africa is regarded as one of the world's major developing economies, given its membership and position in the world markets such as Brazil, Russia, India, China, and South Africa (BRICS). Friedrich and Visser (2005:11; cf. Kalitanyi \& Visser 2010:378) noted that South Africa attracts many international migrants because it is rich in minerals and other resources (Kalitanyi \& Visser 2010:381-382). Many African people leave their countries of origin to come to South Africa in search of jobs to improve their economic situation. Statistics South Africa (2017:27) reported that Zimbabweans constitute the largest number of migrants (approximately 574047 migrants), followed by Mozambique (293 405), Lesotho (160 749), Malawi (78 796), United Kingdom (56 412), Swaziland (38 038), Democratic Republic Congo (31 504), Namibia (30 701), Nigeria (30 314) and many others.

Political situation also has a push and pull factor. Political instability including wars, persecution and violations of human rights are major drivers of internal and international migration. The UNHCR (2015:14) noted that in 2015, the subSaharan Africa region hosted 3.5 million refugees who came from five countries, namely Somalia, South Sudan, the Democratic Republic of the Congo, Sudan and the Central African Republic (UNHCR 2015:14). Thus, South Africa has been a home to many people escaping from war and instability from these countries (Wentzel \& Tlabera 2006: 80-82). Since 2000, an estimated number of more than one million Zimbabweans left their country for South Africa because of political instability. Zimbabweans migrated to South Africa between 2000 and 2008 because of the national economic crisis and the brutality of the ruling party
(ZANU PF) after the 2008 March controversial election (De Jager \& Musuva 2016:15; Hammerstad 2011:1-4; The Human Rights Watch 2008:1).

The contemporary South African context of international migration is also characterised by people moving to the country for business, holiday, leisure, medical treatment and so on (African Tourism Monitor 2013; Kituyi 2017; Saunders 2017; Twining-Ward 2009; World Travel and Tourism Council 2017). Just like the European, American and Asian countries, some African countries like South Africa have witnessed a huge increase in the number of people moving to their countries. The African Tourism Monitor (2013:6-7) noted that Africa's international tourism arrivals grew from 17.4 million in 1990 to 37 million in 2003. This figure sharply increased to 63.6 million in 2012. Notably, South Africa is one of the countries that receives the bulk of the international tourists. For instance, the list of top four major African tourist destinations in descending order between 2011 and 2014 is Egypt (9.9 million), Morocco (9.8 million), South Africa (9.2 million) and Tunisia (6.8 million) (Kituyi 2017:16). In 2015, South Africa received a total of 8903773 tourists (Lehohla 2016:12), which was a decrease from the 9549236 international tourists that the country received in 2014. Of the international tourists who came to South Africa in 2016, 73.8\% came from SADC countries, $1.9 \%$ from other African countries and $24.1 \%$ from overseas countries. This indicates that South Africa is a major 'pull country' of other SADC African countries.

Education is also a feature that draws people to South Africa (Sehoole 2013; University of Oxford 2015:6). The University of Oxford (2015) posits that:
Sub-Saharan Africa is also experiencing a rapid growth in demand, with the population predicted to grow from 1 billion today to 2.4 billion in 2050, and with a set of education systems where demand already far outstrips supply. Almost half of sub Saharan students currently choose to study in South Africa, with most of the remainder studying in France, the USA or UK and other European countries. (p. 6)

Sehoole (2013:53) contended that foreign students are continuously pulled to South Africa by the educational opportunities in the country. The South African government facilitates the immigration of foreign students through offering study permits [and] recruiting students from abroad to meet local needs. The current policy of the South African government includes the provision of scholarships to nonSouth African students to undertake their studies in South Africa (Ramphele 2016:1). Ramphele (2016) added that although the South African government is currently encountering a serious challenge of subsidising university and college fees for South African students from disadvantaged families, following the end of the apartheid era, it is apparent that it has not abandoned its obligation to neighbouring countries and the international community. However, because of better economic opportunities in South Africa, many of the students who come to South Africa to study are not willing to return to their home countries after studies (Sisulu, Moyo \& Tshuma 2007:558). 
Important to note is that when these migrants come to South Africa because of different reasons, they face challenges such as discrimination in the labour market, accusation for stealing jobs from South African natives, exploitation, language problems, lack of legal documentation and lack of access to financial services, hospital services and school services, unemployment, lack of accommodation, etc. (Abel 2017:1-42; Crush \& Williams 2001:8; Fauvelle-Aymar 2015:27; Magezi 2018:260-288; Nzayabino 2010).

Against the given background, a cross-sectional study was conducted to understand South African church leaders' theological perspectives and views that inform migrant ministries in their churches.

\section{Methodology followed in the study Study approach and period}

The study employed a cross-sectional qualitative approach. The data and analysis were conducted between 2017 and 2018.

The study entailed exploring, gaining, understanding and an insight into the theological views and perspectives held by some South African church leaders as representatives of their churches that drive their ministries to international migrants. Accordingly, a qualitative study was deemed appropriate. A qualitative study entails gaining detailed understanding and insight through probing phenomena into detail. A qualitative research is a study approach that is used to gain understanding of underlying reasons, opinions and motivations (Research Methodology.net n.d). The findings are described in thick description (Meaning?). Thus, a qualitative study was the ideal approach as it examines 'people's experiences in detail by using a specific set of research methods such as in-depth interviews, focus group discussions and observations' (Zikmund, Babin, Carr \& Griffin 2013:132). The strength of a qualitative approach for the study was that it shed light, understanding, examine underlying motivations and clarified complex situations of pastors in their congregational natural settings (Leedy \& Ormrod 2010:135). Theological views and perspectives are often not explicit but implicit. The views may be expressed through scriptural texts citation, observing congregational culture, settings and practices that may be less than obvious. Therefore, a qualitative approach is relevant as it probes the situation in detail.

\section{Study population, sampling, inclusion and exclusion criteria, data collection and analysis}

The study focused on church leaders ${ }^{1}$ in Gauteng. A convenient purposive sample of 11 pastors was interviewed. Zikmund et al. (2013:393-394) stated that purposive sampling method is employed where not everyone in the population can be part of the study whilst convenience sampling relies on data collection from population members who are conveniently available to participate in the study. The pastors (sample) were drawn across different individual churches or congregations in Gauteng. Each congregation and its leader (pastor) were considered independently in cases where they fall under one denomination like the Anglican Church. The churches were of mixed races. The church backgrounds were mixed to ensure a diversity of theological views. The mixture comprised Anglican, Baptist, Roman Catholic, Pentecostals, Migrant established churches, Student church, New Apostolic Church and Methodist. The category of churches and the corresponding number churches and the pastors drawn are: Anglicans $[n=2,18 \%]$, Baptists $[n=1,9 \%]$, Roman Catholic $[n=1,9 \%]$, Pentecostals $[n=2,18]$, migrant churches $[n=2$, $18 \%]$, Student churches $[n=1,9 \%]$, New Apostolic Church [ $n=1,9 \%$ ] and Methodist $[n=1,9 \%]$.

The participants comprised 10 males and 1 female. Four of the participants had no theological training but had qualifications in non-theological areas; three participants had Bachelor of Theology degrees; three participants had Honours degree in Theology, and one holds a $\mathrm{PhD}$ in Theology. The participants' period of length in ministry ranges from 2 years to 15 years. The one with the shortest period in ministry has 2 years, whilst the majority (eight) of the participants have been in ministry for a period between 3 and 7 years. The ones with the longest period in ministry are two, whereby one has 10 years and the other 15 years. Eight of the participants were black pastors $(73 \%)$ whilst three were white pastors $(27 \%)$.

The inclusion criteria for the churches were (1) the congregation or church should at least have 10 migrant members, (2) the church or congregation should have been in existence for at least 5 years and (3) the church should have the same or one pastor for at least 2 years at the time of conducting the study. The inclusion criteria for the pastors to participate in the study were (1) the pastors should have been in the leadership of the congregation as a pastor for at least 2 years, (2) the congregation they are leading should at least have 10 migrant church members, (3) the pastors should be available and willing to participate in the interview and (4) the pastor should be willing to sign a consent form. The pastors were initially identified through (1) pastors' fraternal reference followed by (2) snowball sampling. The snowball sampling entailed linking and introducing the researcher to another pastor who fits the criteria for recruitment. The recruitment was done by one of the researchers.

Data collection was performed through 11 in-depth interviews. ${ }^{2}$ Baker and Edwards (2012:2) guided that in responding to the question, 'how many qualitative interviews is enough?', there are a variety of factors that can influence the amount of data the researcher gathers. This is not only measured by the number of interviews but also by the availability of time and resources. In-depth interviewing involves 'conducting intensive individual interviews with a small number of respondents to explore their perspectives on 2.In-depth interviews were preferred because they provide in-depth understanding of an individual's position than a focus group discussion (FGD) that focus on general shared position. 
a particular idea, program, or situation' (Boyce \& Neale 2006:3; Zikmund et al. 2013:149). Each interview was about $1 \mathrm{~h} 30 \mathrm{~min}$ long. The interviews were guided by open-ended questions. An open-ended questionnaire allows respondents to think more about the subject under discussion, enabling detailed answers to the questions (Zikmund et al. 2013:336-341). This created an opportunity for the interviewer to follow up on the emerging issues during the interview.

The research process that was carefully followed for the study entailed the steps described here. (1) A study proposal and protocol were developed, (2) an application for ethics approval was sent, (3) an ethics approval was granted by North-West University Basic and Social Science Research Ethics Committee (BaSSREC), (4) the data collection instrument (open-ended interview guide) was developed and (5) piloted and finalised. (6) Permission to interview respective pastors was sought from respective churches' leaders. (7) A detailed pamphlet outlining the different elements of the study was shared with study participants including a consent form. (8) The participating pastors signed the consent forms in agreement to participate in the study. (9) The interview discussions were recorded, transcribed, coded, analysed and stored in locked lockers

Data analysis was done using a thematic approach. The 11 church leaders were assigned numbers 1 to 11 for confidentiality and to ensure that their responses are not linked to their persons. A thematic analysis approach entails 'identifying, analysing and reporting patterns (themes) within data. It minimally organises and describes one's data in rich detail' (Braun \& Clarke 2006:79). A thematic analysis:

Offers the flexibility for starting data analysis at any time during the project, where there is no association between the data gathered and the result of the process itself. More importantly, it provides the flexibility for approaching research patterns in two ways, i.e. inductive and deductive. (Alhojailan 2012:45)

Verbatim quotes, negative cases and constant comparison approaches were employed to ensure credibility and trustworthiness of data analysis (Babbie \& Mouton 2003).

\section{Findings and discussion of theological views ${ }^{3}$ and perspectives that drive a ministry to migrants}

The first section presents findings from the interviews whilst the second section focuses on discussion of the findings.

\section{Church leaders' views and perspectives on theology that drives migrant ministries}

The pastors' responses were classified into 11 related themes that reflect theological views and perspectives informing migrant ministries. The classified responses are presented in a thematic map (Figure 1).

3.The views of the church leaders are a reflection of their personal theological positions that inform their theology that tends to influence their congregations.

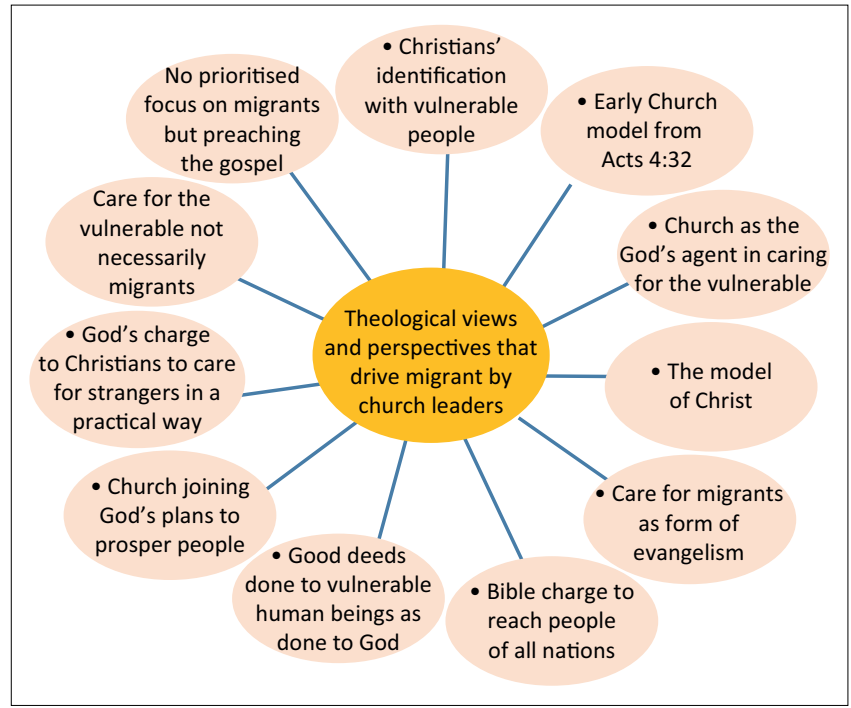

FIGURE 1: Thematic map of pastors' views and perspectives on migrant ministry.

\section{Christians' identification with vulnerable fellow human beings}

The pastors indicated that identification with vulnerable fellow human beings such as migrants is an important biblical teaching that Christians should follow. This view was expressed by most of the pastors $(n=8$, i.e. $72 \%)$, namely 2,3 , $4,5,6,8,9$ and 11 respondents. For example, respondent 11 stated that 'a church has to travel with its migrant members through thick and thin times by identifying with them in their suffering'. This was echoed in a related statement:

'The love he has for his flock forced him to identify with every member who is encountering any kind of challenges. He must identify with others and have mercy, which results in mobilising the church communities to assist those in need.' (Respondent 8)

\section{And affirmed:}

'Just like in Acts 4:32, the church feels that there should be no one lacking among its members. So, the church does its best to meet migrants' challenges. However, the church can only do that by putting itself in migrants' shoes in order to have mercy on their needs.' (Respondent 2)

'Travelling', 'identifying' and 'putting yourself in a migrant's shoes' entail identification with another person in a difficult situation like being a migrant. This empathetic approach indicates a theological justification for churches to engage in migrant ministries. The pastors appealed to Acts 4:32 as a justifying text for identifying with others, oneness and sharing in situations.

\section{Early Church model from Acts 4:32}

Linked to identification with migrant people, is challenge for Christians to imitate the model of the early church as recorded in Acts. The example of the early Church in Acts 4:32 should be a migrant ministry driving theological position (respondents 7 and 9). This was maintained:

'There is no way the current church should not stand in the tradition of the early church where they shared their possessions and everything in common as recorded in Acts 4:32.' (Respondent 7) 
Respondent 9 asserted that 'the contemporary churches should learn their caring practice for the poor and needy from the early church as stated in Acts 4:32'. The respondents cautioned that the church would lose relevance if it abandons the old tradition rooted in Acts 4:32. This would be tantamount to subverting God's word that inaugurated the early church to which they owe their history and tradition.

\section{The Church as an agent of God in looking after vulnerable people}

All respondents reported the notion of the Church as the agent of God with a responsibility of looking after vulnerable people in the society. For instance, as explained:

'Jesus in Matthew 14:13-21 fed those people who were in need. Hence, the Church should represent God and do likewise by looking after the vulnerable, particularly migrants who left everything in their countries of origin for greener pastures in another country.' (Respondent 2)

\section{And reported:}

'Christians are representing God in the world. Hence, they should have mercy as God does when he sees those in desperate situations. This should challenge them to practically intervene in those people's situation to change it from bad to good.' (Respondent 3)

Thus, this indicates that the church leaders perceive the notion of church as God's agent in caring for the vulnerable such as migrants as the theological rationale that should drive their migrant ministries.

\section{The model of Christ}

The church leaders noted the example of Christ as an important theological position justifying migrant ministry. For instance, as stated:

'Things can fall apart when the church creates a different Jesus from that of the Bible. Christian's lives should portray the ethical lives of Jesus. Their lives should be informed by Christ in all matters, which include our treatment of vulnerable like migrants among us.' (Respondent 5)

Respondent 11 added that 'Christians should be like a compassionate Christ, who healed the sick people (Matthew 8 \& Luke 5:12-13) and fed those who were hungry (Matthew 14:13-21)'. Furthermore, it was explained:

'A church can be like Christ when it emulates the exact footsteps of Christ. Following the footsteps of Christ implies that the church should be a loving and caring community to the vulnerable migrants as Christ was to the vulnerable during his earthly ministry.' (Respondent 2)

The church leaders argued that it is imperative to follow the example of Christ as the theological basis for migrant ministries because the church should follow the example of Christ. Christ inaugurated a new caring and loving community of God through his redemptive work. Therefore, the church as a community of God's people is expected to follow his example of care as demonstrated during his earthly ministry.

\section{Care for migrants as form of evangelism}

The church leaders considered taking care of the needs of migrants as a form of evangelism, which is a key aspect of the churches' role. Three respondents (7, 10 and 11, i.e. 27\%) strongly held this view. They maintained the view that caring for migrants' needs is a form of evangelism, hence it should be churches' ministry focus. As stated:

'Looking after the vulnerable migrants is a form of evangelism that the church is called to do. Therefore, it is this understanding that drives my church to look after migrants because we reach them through addressing their needs.' (Respondent 10)

Respondent 11 substantiated this migrant ministry theological motivation by appealing to James 2:14-18. He explained that:

'James 2:14-18 is a good text that states that good works are a form of evangelism. The aforementioned text explains that if Christians say they have faith, then they should show it in their actions.' (Responded 11)

And added:

'Christian works do not save people (Christians) because Christians are already saved but it is a matter of appropriate response to believers' faith in Christ that enhances their evangelism.' (Respondent 11)

Referring to the same James text respondent argued:

'Words without actions are dead. Migrants grow their faith in the Lord because they view the church as a loving and caring community and non-Christians will be also converted because of our good work.' (Respondent 7)

The church leaders perceive the notion of migrant ministries as a form of evangelism. The migrant ministries call people to church and at the same time these ministries authenticate and validate the churches' Christianity.

\section{Biblical charge to reach people of all nations}

The Bible's concern and charge to reach people of all nations is another migrant theological ministry (motive?) pointed out by church leaders. Respondent 6 explained that the Bible charges us to reach people of all nations in 'words and deeds'. He maintained that his 'theological convictions arise from the Great Commission in Matthew 28:16-20 whereby Jesus charges Christians to reach people of all nations'. He added:

'The Great commission is interconnected with the notion of the universal love of God, who loves all people regardless of their nationalities. So, the church should love all migrants by not discriminating them. This understanding challenges my church to care for all migrants by looking after their needs as the church is currently doing.' (Respondent 6)

\section{Good deeds done to vulnerable human beings as done to God}

An understanding that doing good deeds to vulnerable people is being done to God raises consciousness and awakens the realisation that good deeds are expected by God. Respondents 2, 10 and 11 reported that their migrant 
ministries are driven by the theological rationale that whenever they do good deeds to the vulnerable people, they are doing it to God. These three church leaders $(2,10$ and 11) explicitly stated that Matthew 25:35 drives their church migrant ministries because Jesus equated Christians' relationship to the need with a relationship to himself. It was elaborated that Matthew 25:35 conveys:

'When Christians look after the needy people among them, they are doing it to Jesus Christ or God. Hence, it is this understanding that drives my church to honour Christ by addressing the needs of the vulnerable migrants in his church.' (Respondent 2)

\section{Church joining God's plans to prosper people}

Migrant ministry was viewed as a church joining God's plans to prosper people, which should be lauded. Respondent 10 reported that migrant ministry relates to churches joining hands with God in his plan to prosper all people. Hence, this is a theological rationale that drives his church to do migrant ministry. He stated that this theological position arises from Jeremiah 29:11, where the Bible states that God has a plan to prosper them and not to harm them. The respondent added that:

'God has a plan of peace, not sorrow for all humankind. Therefore, when his church is helping the vulnerable people (i.e. migrants), it is taking God's plan for everyone seriously. This is in conjunction with His (God's) mission to prosper all humankind.' (Respondent 10)

\section{God's charge to Christians to care for strangers in a practical way}

God's command and expectation for Christians to care for strangers in a practical way is another stated theological motivation for migrant ministry. Respondent 8 affirmed that looking and caring for migrants is a direct answer to God's command for his people to care for strangers amongst them. Without mentioning specific scriptural texts to substantiate his biblical position, the church leader added that the emphasis for God's people to look after migrants is a pervasive teaching in the Old and New Testaments'.

\section{Care for the vulnerable not necessarily migrants}

Some church leaders (respondent 1 and 3) viewed migrant ministry as a ministry that should not have a specific focus. Instead, the Bible encourages Christians to care for all the vulnerable. They argue that the Bible's concern is to look after the vulnerable. For instance, as reported:

'I do not see migrants as different from vulnerable people within the church. This is because there is no specific focus in Scripture for churches to look after migrants'. He added that 'I understand that migrants have unique challenges that require specific solutions, but this does not mean that they (migrants) are given priority in Scripture than other vulnerable groups of people.' (Respondent 1)

Respondent 3 expressed a similar point that 'the Bible's general concern is to look after the vulnerable or the needy, so migrants cannot be separated from the rest of the vulnerable church members'. However, this does not mean that these churches do not assist migrants when the need arises.

\section{No prioritised focus on migrants but preaching the gospel}

Two respondents ( 1 and 3) (18\%) reported that their churches do not have migrant ministries because the primary purpose of the church is to preach the gospel not to attend to physical needs of the vulnerable. As stated:

'Ibelieve that the church is not a Non-Governmental Organisation that looks after the physical needs of people. The role of the church is to preach the gospel that grants people eternal life.' (Respondent 1)

In a different way, but echoing the same sentiment as respondent 1 , another respondent stated:

'The church should focus on the return of Christ by preaching the gospel that gives eternal life to sinners. This world is a passing world, Christians are looking forward to the world to come. The focus of the church should not lie in this life but in the world to come. This is to say that people should not be worried much about their present situation, but they should be concerned of what will happen when they die.' (Respondent 3)

In bringing Scripture to support his point, a respondent argued that:

'Matthew 6:19-34 is a good text to challenge Christians not to focus on material things of this word; instead, they should focus in seeking first the Kingdom of God or invest their treasures in heaven.' (Respondent 3)

\section{Evaluation and discussion of the views and perspectives on theological basis migrant ministries}

The church leaders comprised mixture of pastors from different denominations with different levels of theological education ranging from no theological training to $\mathrm{PhD}$ in theology. The respondents have also been in church leadership for different lengths of period ranging from 2 to 15 years. Certainly, this diversity results in inevitable differences in theological understanding and positions including that of the researchers. Thus, in discussing these views, this diversity is considered. The discussion and analysis employed an approach where scriptural texts were considered in their historical contexts. Negative cases and constant comparison were weaved with theological doctrines and scriptural texts to evaluate and bring insight from the theological views advanced by the church leaders on migrant ministry.

\section{Identification and incarnation}

Identification with migrants (Ac 4:32) as a driving theological motive is a worthwhile view. Although Acts 4:32 implies identification theology, the theology of identification seem undeveloped and not well thought through. This theological position could be complemented and strengthened by the doctrine of the incarnation, which the church leaders did not mention. The doctrine of incarnation (Jn 1; Col 1:9; Heb 1-2) advances the notion of the identification of the transcendent God with sinful humanity. The theology of incarnation can serve as an exemplary doctrine that church leaders could employ to strengthen the identification of theological view and position. At the same time, the early church model 
(Ac 4:32ff) where Christians brought everything they had and cared for each other could be strengthened. The church leaders only mentioned the good aspects of the early church and yet there were challenges that arose in the same church because of caring ministry. These developments reveal the idea of Christians' tension with sin that believers of the early Church experienced in their caring ministry. For instance, sin clearly arose in Ananias and Sapphira's story in Acts 5:1-11 where the couple pledged to sale their land and give the money to the church but after the sale, the couple decided to keep some of the money. This unfaithful act resulted in their death. Although the story of Acts 4:32 reveals a paradigm and practical possibility to operate as a theological basis for churchs' migrant ministries, the realities of fallenness should be noted. Thus, a conceptualisation of the reality of Christian struggle (Rm 7:19ff) assists in raising consciousness on the reality of the Christian spiritual tension and struggle. This is important as there is already a tension that Christians encounter in caring for other people such as migrants.

\section{The church as God's agent}

The view of the church as an agent of God in looking after vulnerable people is a reasonable theological rationale because God, in and through Christ has both inaugurated and established his new community (comprised of Jews and Gentiles) that represent him (God) in the world. Thus, representing God entails Christians embodying the loving and compassionate character of God in the world. This indeed challenges churches to practical actions. However, what seemed conspicuous by the silence of the church leaders in their responses is that they seem not to acknowledge the doctrine of the sinfulness of humanity even when they are saved. In this light, it is critical that the challenge for people to represent God be understood from the perspective of human limitation because of sinful nature that people continue to battle with (cf. Rm 7). Christ also provides an important example. However, it is important to guard against a superficial understanding of this theological category as it may be taken to imply that because Christ healed the sick and fed the hungry people (i.e. Mt 8; Lk 5:12-13) (Mt 14:13-21), therefore the churchs' migrant ministries should do likewise. With this in mind, the theological rationale of following the example of Christ should be understood as limited.

\section{Migrant ministry as evangelism}

Viewing migrant ministry as a form of evangelism as justified from James 2:14-18, which says if Christians say they have faith then they should show it in their actions, is inappropriate. James seems to be referring to true faith that has practical actions not good works as form of evangelism. The church leaders are indicating appropriate, acceptable and relevant responsive theology but using less relevant biblical text. It is clear from the wider context of Scripture that Christians' faith should be accompanied by good works and it is through these works that people will come to know Christ and get saved. This theological position was summed by Chester (2004) as follows:
[S]ocial activity is the consequence of evangelism, social activity can be a bridge to evangelism, and social activity is the partner of evangelism. Social action, then, can precede, accompany or follow evangelism. (pp. 61-62)

\section{Reaching all the nations}

The notion of God's concern to reach all people as a theological rationale for churchs' migrant ministries is equally justifiable. However, this position is not well developed. The desire for God to reach all people emanate from the Great Commission in Matthew 28:16-20, which charges Christians to reach people from all nations. As well, the notion of people belonging to and worshipping one God challenges the churches to avoid the discrimination of migrants amongst the churches and beyond. At the same time, the theological rationale of Christians honouring God by looking after migrants is explicit in Matthew 25:35ff. However, the church leaders seemed to be silent about this passage and perspective.

\section{Prospering the people of God}

The notion of joining hands with God in his plan to prosper people (Jr 29:11) as a theological basis for migrant ministry is highly questionable. The context of this passage is the Israelites who were in Babylonian captivity whereby God specified 70 years slavery (Jr 29:10). In the context of the Israelites being in captivity for 70 years, God assures them that it was not the end because he was going to intervene and redeem them from their Babylonian bondage. This was fulfilled in later years. The conception of the churches' obedience to God's command to look after strangers amongst them is a justified theological rationale in driving churches migrant ministries. The charge for the church to look after migrants is indicated in the law of God in the Old and New Testaments (i.e. Ex 22:21-22; Lv 25:35-36; Jr 22:3; Heb 12:2; Mt 25:35).

Vulnerable versus migrants: The views expressed by some church leaders that they do not have structured migrant ministries because the Bible's concern is to look after the vulnerable not necessarily migrants as a special group cannot be sustained. The Bible urges Christian's to look after migrants. The command for God's people to look after migrants or strangers is clear in both the Old (i.e. Ex 22: 21-22; Lv 25:35-36; Jr 22:3) and New Testament (Heb 12:2; Mt 25:35). These could be embraced by church leaders to inform their ministries dispel their argument that seem to be based on personal opinion than Biblical texts. It is noted that usually when the Old Testament charges God's people to look after aliens amongst them, it always classifies them with other vulnerable people such as widows and orphans (e.g. Dt 10:18; Ex 22:21-24). However, the classification of migrants with other vulnerable groups of people in Israel such as orphans and widows cannot be justified as a theological basis for churches not having migrant ministries. These three groups of people (i.e. widows, orphans and migrants) have different challenges that require specific responses or solutions. Therefore, with many scriptural 
references that command God's people to look after the vulnerable people such as migrants, churches should consider targeted migrant ministries.

Conversion only: The view that churches should not focus on addressing material needs of migrants but focus on conversion through preaching the gospel for people to have eternal life cannot be sustained. This is a weak and old argument. The dichotomy between 'spiritual and material', 'word and deed' or 'social and spiritual' was resolved four decades ago during Lausanne Congress in 1974. The dichotomy has been debated and clarified across the Christian divide through integral or holistic mission discussions. Christians across the divide agree that integral mission is the appropriate way of doing Christian ministry whereby the gospel entails actions that integrate word and deed (Bosch 1991:512; Chester 2004:61-62; Magezi 2018b:124; Micah Network 2001:1). Thus, whilst our focus is not to revisit the holistic/integral mission debate, it is worthwhile to note that many scholars maintain that holistic mission is deeply Biblical although there has been a tension between evangelism (spiritual) and social gospel (physical help) Langmead 2012:1-8; Myers 2010:120-121; Samuel \& Sugden 2003:71. Integral or holistic mission is clearly taught in the scriptures (e.g. Ja 2:14-18; Mt 25:31ff).

\section{Superficial Biblical understanding}

The observations that can be made from the given discussion are that in many instances the church leaders had superficial understanding of the Biblical texts, lacked contextual understanding of some texts and a theology that was not well thought out. This is understandable considering that some of these church leaders had no theological training $(n=4,36 \%)$ and the majority $(n=6,55 \%)$ had a Bachelors' degree or Honours degree in theology, with one $(9 \%)$ holding a $\mathrm{PhD}$. This implies that their level of theological understanding is limited. Migrant ministry as a holistic ministry requires well thought out theological basis. However, there has been very limited in-depth critical theological reflection on holistic ministries. Myers (2010:120) who is one of the leading theologians in holistic ministry and has been part of the holistic/integral mission movement for four decades with other theologians such as Padilla, Stott, Samuel, Sugden and many others, observes that two aspects that characterise the current lacuna in integral mission. Firstly, holistic mission (evangelism and social action) is now a historical footnote. Secondly, people and organisations are simply getting on with transformational development (integral mission) with hardly any or no reflection. Myers (2010:120-122) further noted that, whilst holistic mission was embraced post-1980s with the theological foundation laid at Lausanne 1974, there has been no further conceptualisation and theological understanding of how things would work. Therefore, Myers (2010) laments that:

There is very little, if any, serious research by Christian practitioners - very few $\mathrm{PhD}$ studies, and almost no academic research into transformational development. There is very little new theological reflection; we are resting on the excellent work done in the 1980s. There is no new ecclesiology, and yet the question of the relationship between the Christian relief and development agency and local churches remains unclear. The bottom line is this: for the last twenty years, evangelical holistic mission activists have acted. They have gone out and done transformational development. Doing is good. But there is more to doing than just acting. (p. 121)

Therefore, Magezi (2018b:126) commented that the situation 'reflects a dearth and a shelving of serious theological reflection and a kind of integral mission theological fait accompli'. However, Myers (2010) argument does not discount the influential work done by scholars such as David Bosch (1991) considering his ground-breaking work in 'Transforming Mission' including the bodies like the Micah movement and the Communion of Reformed Churches' Accra Confession. His argument is that many of these theologians' work does not substantially and meaningfully work from the biblical text to advance solid arguments but rather like commentators of integral mission. Considering the diverse and weak theological positions articulated, migrant ministry as holistic ministry, has a shaky theological basis. Therefore, it is not surprising that many churches and church leaders remain aloof when there is abuse of migrants or xenophobia. Church actions arise from a sound theological base.

\section{Conclusion}

The theological motivations that drive South African churches' migrant ministries are diverse. Some of these motivations are theologically sound, whilst others are weak and superficial. The overall observation made is that migrant ministry as holistic ministry requires well thought theological theory to drive church actions. Currently, there is a gap in migrant ministry theological reflection just like in broader holistic ministry.

\section{Acknowledgements Competing interests}

The authors have declared that no competing interests exist.

\section{Authors' contributions}

All authors contributed equally to this work.

\section{Ethical consideration}

Ethics approval for the study was granted in 2016 by the Basic and Social Sciences Research Ethics committee (BaSSREC) of the North-West University, Vanderbijlpark. Ethics number: NWU-HS-2016-0219.

\section{Funding information}

This research received no specific grant from any funding agency in the public, commercial or not-for-profit sectors.

\section{Data availability statement}

Data sharing is not applicable to this article as no new data were created or analysed in this study. 


\section{Disclaimer}

The views and opinions expressed in this article are those of the authors and do not necessarily reflect the official policy or position of any affiliated agency of the authors.

\section{References}

Abel, M., 2017, 'Labour market discrimination and sorting: Evidence from South Africa', Southern Africa Labour and Development Research Unit 205(1), 1-42. https://doi.org/10.1596/1813-9450-8180

African Tourism Monitor, 2013, African Development Bank, viewed 29 October 2020 from https://www.afdb.org/fileadmin/.../September_2013_-_Africa_Tourism_ Monitor.Bankpdf.

Alhojailan, M.I., 2012, 'Thematic analysis: A critical review of its process and evaluation', West East Journal of Social Sciences 1(1), 36-47.

Babbie, E. \& Mouton, J., 2003, The practice of social research, Oxford University Press, Cape Town.

Baker, S.E. \& Edwards, R., 2012, How many qualitative interviews is enough?, Discussion Paper, viewed 09 November 2018, from eprints.ncrm.ac.uk/2273/4/pdf.

Bosch, D.J., 1991, Transforming mission, Orbis, New York, NY.

Boyce, C. \& Neale, P., 2006, Conducting in-depth interviews: A guide for designing and conducting in-depth interviews for evaluation input, Pathfinder International, viewed 29 April 2020, from http://www2.pathfinder.org/site/DocServer/m e tool series indepth interviews.pdf?docID=6301.

Braun, V. \& Clarke, V., 2006, 'Using thematic analysis in psychology', Qualitative Research in Psychology 3(2), 77-101. https://doi.org/10.1191/1478088706 qp063oa

Bush, J.E., n.d., Practical theology in church and society, viewed 10 August 2019, from https://www.wesleyseminary.edu/wp-content/uploads/2015/10/PracticalTheology-in-Church-and-Society-1.pdf.

BusinessTech, 2017, How many foreigners really live in South Africa? viewed 23 March 2020, from https://www.BusinessTechbusinesstech.co.za/News/Trending

Cahalan, K.A. \& Mikosk, G.S. (eds.), 2014, Opening the field of practical theology: An introduction, Rowan \& Littlefield, New York, NY.

Chester, T., 2004, Good news to the poor: Social involvement and the Gospel, Intervarsity Press, Nottingham.

Chisale, S.S., 2016, 'Bishop Paul Verryn's pastoral response towards unaccompanied refugee minors', HTS Teologiese Studies/Theological Studies 72(2), a3411. https:// doi.org/10.4102/hts.v72i2.3411

Crush, J. \& Williams, V., 2001, 'Making up the numbers: Measuring illegal immigration to South Africa', Migration Policy Brief No. 3, The Southern African Migration Programme, viewed 12 August 2017, from samponline.org/wp-content/ uploads/2016/10/brief3.pdf.

Crux, 2019, South African bishop says Church must tackle xenophobia, viewed 28 April 2020, from https://cruxnow.com/church-in-africa/2019/09/south-african-bishopsays-church-must-tackle-xenophobia/.

De Jager, N. \& Musuva, C., 2016, 'The influx of Zimbabweans into South Africa: A crisis of governance that spills over', Journal Africa Review 8(1), 1-30. https:// doi.org/10.1080/09744053.2015.1089013

Elsdörfer, U., 2019, Spirituality in diversity: South East Asia meets South Africa Towards a global view of spiritual counselling, 2 nd edn., AOSIS, Cape Town.

Fauvelle-Aymar, C., 2015, Immigration and the South Africa Labour market, MiWORC Working Paper No2, University of the Witwatersrand, African Centre for Migration \& Society, viewed 17 October 2017, from http://www.miworc.org.za/.../MiWORC WorkingPaper-2-Immigration-and-SA-labour-mark.

Food and Agricultural Organization for United Nations, 2015, 'The impact of natura hazards and disasters on agriculture, food security and nutrition', viewed 27 March 2020, from https://www.fao.org/3/a-i4434e.pdf.

Friedrich, C. \& Visser, K., 2005, Is Entrepreneurial Education at South African Universities Successful?: An Empirical Example, viewed 24 June 2020, from https://journals.sagepub.com/doi/abs

Gilbert, S.M. \& Chiumia, S., 2016, 'Factsheet: Where do South Africans international migrants come from?', in African Check: Setting facts from fiction, viewed 27 August 2017, from hitps://africacheck.org/factsheets/geography-migration/.

Goldin, I., 2016, How immigration has changed the world - For the better, viewed 27 April 2020, from https://www.weforum.org/agenda/2016/01/how-immigrationhas-changed-the-world-for-the-better/.

Hammerstad, A., 2011, ‘Linking South Africa's immigration policy and Zimbabwe Diplomacy', Policy Briefing 42, South African Foreign Policy and African Drivers Programme, viewed 23 June 2018, from https://www.saiia.org.za/policybriefings/...south-africa...immigration...zimbabwe.../fil.

Hanciles, J., 2008, Migration, Diaspora communities, and the New Missionary Encounter with Western Society, viewed 23 April 2020, from https://www. lausanneworldpulse.com/themedarticles-php/975/07-2008.

Human Rights Watch, 2008, Neighbors in Need: Zimbabweans Seeking Refuge in South Africa, Human Rights Watch, New York, viewed 11 November 2017, from https://www.hrw.org/.../2008/.../neighbors-need/zimbabweans-seeking-refugesouth-africa.
Kalitanyi, V. \& Visser, K., 2010, 'African immigrants in South Africa: Job takers or job creators', SAJEMS NS 13(4), 376-390.

Kapur, S., 2020, Trump halts immigration for 60 days. Here's what the president's order means, viewed 28 April 2020, from https://www.nbcnews.com/politics/white-house/ trump-s-immigration-ban-raises-more-questions-answers-here-s-n1188946.

Kituyi, M., 2017, Economic development in Africa report 2017, Tourism for Transformative and Inclusive Growth, United Nations Conference on Trade and Development (UNCTAD), viewed 07 October 2018, from unctad.org/en/ PublicationsLibrary/aldcafrica2017_en.pdf.

Lajčák, M., 2018, Why we need a global understanding of migration, viewed 5 March 2020, from https://www.weforum.org/agenda/2018/01/global-migration-canbe-a-success/.

Langmead, R., 2012, 'Paradigm shifts in missiology: From Christendom to the missional church'. Paper presented at Myanmar Institute of Theology, viewed 12 missional church'. Paper presented at Myanmar Institute of Theology, viewed 12
April 2018, from http://rosslangmead.50webs.com/rl/Downloads/Resources/ April 2018, from http://ross
MissionalChurchNov12.pdf.

Langmead, R., 2013, 'What is missiology?', Missiology: An International Review 42(1), 67-79. https://doi.org/10.1177/0091829613480623

Leedy, P.D. \& Ormrod, E.J., 2010, Practical research: Planning and design, 9th edn., Pearson Education, Boston, MA.

Lehohla, P., 2015, 'Tourism. Statistics South Africa', viewed 12 November 2018, from www.statssa.gov.za/publications/Report-03-51-02/Report-03-51-022015.pdf.

Louw, D.J., 2014, Wholeness in hope care on nurturing the beauty of the Human soul in spiritual healing, Lit Verlag, Wien.

Louw, D.J., 2015, 'Compassion fatigue: Spiritual exhaustion and the cost of caring in the pastoral ministry: Towards a "pastoral diagnosis" in caregiving', HTS Teologiese Studies/Theological Studies 71(2), Art. \#3032, 10 pages. https://doi.org/10.4102/ Studies/Theologicc
hts.v71i2.3032

Magezi, C., 2018, 'Theological understandings of migration and church ministry model: A quest for holistic ministry to migrants in South Africa', PhD thesis, North West University, Potchefstroom.

Magezi, V. \& Mutowa, C., 2018, 'Towards doing practical integral mission: A Nazarene Compassionate Ministries (NCM) reflection in Africa', Acta Theologica 38(2), 123-144. https://doi.org/10.18820/23099089/actat.v38i2.8

Magezi, V., 2019, 'Practical theology in Africa: Situation, approaches, framework and agenda proposition', International Journal of Practical Theology 23(1), 115-135. https://doi.org/10.1515/ijpt-2018-0061

Mail and Guardian, 2010, 'Paul Verryn: What went wrong?', Mail and Guardian, 29 January 2020, viewed 08 April 2020, from https://mg.co.za/article/2010-01-29paul-verryn-what-went-wrong/.

Matheny, P.D., 2011, Contextual theology: Drama of our times, Pickwick Publications, Eugene, OR.

Micah Network, 2001, Integral mission, viewed 10 April 2018, from http://www. micahnetwork.org/integral-mission.

Miller-Mclemore, B.J., 2012, 'Five misunderstandings about practical theology' International Journal of Practical Theology 16(1), 5-26. https://doi. org/10.1515/ ijpt-2012-0002

Myers, B.L., 2010, 'Holistic mission: New frontiers', in: B. Woolnough \& W. Ma (eds), Holistic mission: God's plan for God's people (Oxford: Regnum Books International), pp. 119-127.

Naudé, W., 2008, 'Natural disasters and international migration from Sub-Saharan Africa', Migration Letters 6(2), 1741-8984. https://doi.org/10.33182/ml.v6i2.75

Nzayabino, V., 2010, 'The role of refugee established churches in integrating forced migrants: A case study of Word of Life Assembly in Yeoville, Johannesburg', HTS Teologiese Studies/ Theological Studies 66(1), Art. \#290, 9 pages. https://doi. org/10.4102/hts.v66i1.290

Ramphele, M., 2016, Immigration and education: International students at South African Universities and Technikons, Migration Policy Series No. 12, Southern African Migration Project, Cape Town, viewed 05 August 2018, from samponline. org/wp-content/uploads/2016/10/Acrobat12.pdf.

Research Methodology Net, n.d., Exploratory research, viewed 21 March 2018, from http://research-methodology.net/research-methodology/research-design/ exploratory-research/.

Samuel, V. \& Sugden, C., 2003, 'Transformational development: Current state of understanding and practice', Transformation 20(2), 71-77. https://doi.org/ 10.1177/026537880302000203

Saunders, G., 2017, The South African Tourism sector: An economic outlook, viewed 07 August 2018, from https://www.sanparks.org/.../tourism.../the-south-africantourism-sector-an-economic-.

Sehoole, C.T., 2013, Students mobility and doctoral education in South Africa, UP Space Institutional Repository, viewed 13 September 2018, from https:// repository.up.ac.za/handle/2263/17439.

Statistics South Africa, 2017, Statistical release P0302: Midyear population estimates 2017, viewed 12 September 2017, from http://www.statssa.gov.za/publications/ P0302/P03022017.pdf

Schjonberg, M.F., 2017, 'One disaster after another: Coping with compassion fatigue can be a challenge', The Episcopal Church, viewed 7 April 2020, from http://www. episcopalnewsservice.org.

Sisulu, E., Moyo, B. \& Tshuma, N., 2007, 'The Zimbabwean community in South Africa', in S. Buhlungu, J. Daniel \& R. Southall (eds.), State of the Nation South Africa 2007 pp. 552-553, HSRC Press, Cape Town.

Smither, E.L., 2011, 'Missão integral [holistic mission or the "whole Gospel”] applied Brazilian evangelical models of holistic mission in the Arab-Muslim world', Verbum et Ecclesia 32, 1-11. https://doi.org/10.4102/ve.v32i1.483 
TNE Nansen Initiative, 2015, 'Disasters, climate change and human mobility in Southern Africa: Consultation on the draft protection agenda', Background Paper by Nansen Initiative Southern Africa Consultation in cooperation with th Development and Rule of Law Programme (DROP) at Stellenbosch University, viewed 22 June 2017, from drop.sun.ac.za/.../08052015-Nansen-InitiativeSouthern-Africa-Background-Paper.pdf.

The Southern African Catholic Bishops Conference, n.d., 'The pastoral care of Migrants and Refugees (M\&R)', viewed 27 April 2020, from https://sacbc.org.za/pastoralcare-of-migrants-and-refugeesmr/.

Twining-Ward, L., 2009, Africa Region's Finance and Private Sector Development Department (AFTFP): Sub Saharan Africa Tourism Industry Research, viewed 08 May 2018, from siteresources.worldbank.org/INTAFRSUMAFTPS/.../FinalSSA TourismRpt1118.pdf.

United Nations Human Rights (UNHR), 2015, Migration, human rights and governance. Hand Book for parliamentarians no 24, Published by Inter-Parliamentary Union 2015. Geneva, Switzerland.

United Nations Human Rights (UNHR), 2015, Global trends forced displacement in 2015: Trends at a glance 2015 in review, viewed 07 October 2018, from www. unhcr.org/576408cd7.pdf.
University of Oxford, 2015, International trends in Higher Education 2015, University of Oxford, London.

Wentzel, M. \& Tlabera, K., 2006, 'Historical background to South African migration', in P. Kok, D. Gelderblom, J. Oucho \& J. Van Zyl (eds.), Migration in South and Southern Africa: Dynamics and determinants, pp. 71-95, HSRC Press, Cape Town.

World Council of Churches (WCC), 2019, 'World Council of Churches Pastoral letter based on Pilgrim Team Visit to South Africa on Gender-Based Violence and Femicide and Xenophobia 16 December 2019', viewed 28 April 2020, from https:// Femicide and Xenophobia 16 December 2019, viewed 28 April 2020, from https:// www.oikoumene.org/en/resources/documents/wcc-programmes/world-council-
of-churches-pastoral-letter-based-on-pilgrim-team-visit-to-south-africa-ongender-based-violence-and-femicide-and-xenophobia/.

World Travel and Tourism Council, 2017, 'Travel Tourism \& Tourism Economic impact 2017 South Africa', World Travel and Tourism Council, viewed 13 July 2018, from https://www.wttc.org/-/media/files/reports/economic-impact.../southafrica 2017.pdf.

Zikmund, W.G., Babin, B.J., Carr, J.C. \& Griffin, M., 2013, Business research methods, 9th edn., International edition. Cengage Learning, Boston. 